撮影体位を, とらせることなく撮影可能となった。

303. ディジタル画像用高階調レーザプリンタの開発(そ の 2)

$$
\begin{array}{r}
\text { 侏日立メディコ研究開発センタ } \\
\text { ○大森幹之・石川 謙 } \\
\text { 松岡 敬・岡部哲夫 }
\end{array}
$$

従来のマルチフォーマットカメラに代わるディジタル 画像のハードコピー化装置として, 高階調のレーザプリ ンタを開発した．今回は，同一のテストパターン画像に よるレーザプリンタとマルチフォーマットカメラの出力 画像を定量的に比較・測定した。その結果, レーザプリ ンタの出力画像が次の点で優れていることを明らかにし た. (1)ベース濃度から濃度值 3 までの直線的な入出力 特性で濃度分解能が高く, 0.01 の濃度差まで再現可能で ある. (2)空間分解能がよく, 特に 1 枚撮りの空間周波 数带域はマルチフォーマットカメラの $2 \sim 3$ 倍である。

304. ティシタル画像用高階調レーザプリンタの開発(光 の 1)

楋日立メディコ

○飯田吉彦・鈴木正憲・石川謙 池田 満・岡部哲夫

ディジタル画像のハードコピー化装置として, 高階調 レーザプリンタを開発した．今回は臨床画像の出力結果 をマルチフォーマットカメラと画質および診断情報につ いて比較を行ったので報告する。

臨床画像の評価の結果, レーザプリンタ出力像は, 空 間分解能, 濃度分解能が良いので，マルチフォーマット カメラ出力像より次の点で侵れているとの評価を得た。

(1) 頭部血管のDSA 像では血管の走行が立体的に見 え，細い血管まで明瞭である。

（2）胸部 X 線フィルム像は, 軟部組織や骨・気管支が 明瞭であり，原画像が忠実に再現されていることを確認 した。

305. 富士イメージングカメラの光ファイバ伝送システ ムについて

三重大学医学部附属病院中央放射線部

○荒木昭信

富士機器工業株式会社開発部 秋本泰造

富士メディカルシステム构会社技術部

管津 進

〔目的〕イメージングカメラを光ファイバで長距離伝 送するシステムを設置に伴い，CT 装置の近くにカメラ を設置, 光ファイバで $100 \mathrm{~m}$ 離れて設置, 同軸ケーブル
で $100 \mathrm{~m}$ 離れて設置した場合の各特性を比較検討した。

〔結果]（1)各出力信号波形の比較では光ファイバは光 增幅により $0.01 \mathrm{~V}$ 增幅, 同軸ヶーブルは $0.02 \mathrm{~V}$ の減衰 とピーク值 $0.08 \mathrm{~V}$ 減衰と波形劣化があった. (2)光ファイ バニニットの周波数特性では $40 \mathrm{MHZ}$ まて多化なく再 現している. (3)ミクロフォトメータによる測定では光フ アイバと近くに設置した場合は同一であるが同軸ケーブ ルでは解像度低下がみられた，光ファイバ伝送システム は画像劣化なく近赤外波長より電気雑音の影響を受けず 有効である。

\section{6. 自現機直結型透視撮影装置の開発}

日立メディコ柏工場

○神保美明・石塚達洋

隠田建與・塚原拓夫

北海道大学医学部放射線科

入江五朗

北海道大学医学部附属病院放射線部 千田昌美

$\mathrm{X}$ 線写真により診断を行う, 総合 $\mathrm{X}$ 線診断システムに おいてカセッテレスX線透視撮影台とフィルム自動現 像機との直結は, フィルム処理の迅速化, 省力化の点で 大きい効果がある，われわれは，これをフィルム般送系 の移動が常時行われる断層機能付 X 線 TV用カセッテ レス透視撮影台に取り入れ開発を行い，透視撮影台がど のような位置にあっても，つまり天板の起倒動や速写装 置の移動に関係なく，撮影済みフィルムを自動現像機へ 連続的に確実に送り込む機構を実用化した。

その結果，フィルム処理の迅速化，雀力化の効果と同 時に診断の即時的判断が可能となり, 診断の質的向上も 得られた。

307. X 線 TV 断層装置日立 TU-210LZ の実用化 (侏日立メディコ柏工場 ○西村俊平

信大付属病院中央放射線部 春日敏夫

搳日立メディコ柏工場

白木英成・館外志雄・大久保彰

日本アビオ二クス(猘)

皆上 滋・本多昌八郎

〔目的〕 1 回の X 線曝射で任意の断層面の観察がリ アルタイムに可能で, 被検者への被曝線量の低隇に優れ たシステムの開発を目的とした。

〔結果〕 1.TV断層像がリアルタイムに得られた。 2. 設定截断面 $150 \mathrm{~mm}$ の範囲で $2.5 \mathrm{~mm}$ ピッチの断 